\title{
Progressive Attraction: On the Use and Grammaticalization of Progressive Aspect in Dutch, Norwegian, and German
}

\author{
Bergljot Behrens \\ University of Oslo \\ Monique Flecken \\ Heidelberg University/Radboud University \\ Mary Carroll \\ Heidelberg University
}

\begin{abstract}
This paper investigates the use of aspectual constructions in Dutch, Norwegian, and German, languages in which aspect marking that presents events explicitly as ongoing, is optional. Data were elicited under similar conditions with native speakers in the three countries. We show that while German speakers make insignificant use of aspectual constructions, usage patterns in Norwegian and Dutch present an interesting case of overlap, as well as differences, with respect to a set of factors that attract or constrain the use of different constructions. The results indicate that aspect marking is grammaticalizing in Dutch, but there are no clear signs of a similar process in Norwegian.
\end{abstract}

\section{Introduction.}

\subsection{General Introduction.}

The present paper aims to contribute to our understanding of how verbal aspect is used, conceived, and constrained in three closely related languages, Dutch (as spoken in the Netherlands), Norwegian, and German, in which explicit marking is not obligatory in any context. We look at native speakers' event descriptions and compare the use of several different types of morphosyntactic forms, all encoding the aspectual

\footnotetext{
* We would like to thank Hana Andresen, student assistant at the University of Oslo at the time of data collection, for help with the collection and transcription of the Norwegian data. We would also like to thank the DFG for financial support of this study.
} 
distinction tentatively described as "ongoing event". In the linguistic literature on aspect, these forms are labeled markers of progressive aspect (see section 1.2 below). Aspect markers and their semantic interpretation have been studied extensively from a theoretical point of view, not least with respect to English, but empirical studies that compare their use in comparable contexts across languages have been conducted to a lesser extent. It is also a highly relevant question as to what extent aspectual forms generally can be viewed as "progressives" and how this can be assessed. This question is at the center of the present crosslinguistic comparison, which analyzes native speakers' responses to the same visual, nonlinguistic input (video clips, showing events of different types). Specific properties of the situations presented in video clips were varied on a systematic basis in order to trace factors that lead to explicit marking of aspect in languages in which aspect marking is not obligatory in any context. The comparison is thus carried out in an empirical context in which established research procedures in the field of temporal semantics are complemented by experimental analysis.

The investigation of Dutch, German, and Norwegian is particularly interesting, since the linguistic means in the three languages partly overlap in specific language pairs. For example, posture verb constructions are available in Norwegian and Dutch, while constructions with a preposition are available in Dutch and German. By means of the crosslinguistic comparison, analyzing the variables and syntactic constraints on use, we aim to identify the contexts that play a role in attracting the use of the two types of constructions. Relevant to the study is also the extent to which one can speak of a possible grammaticalization of specific aspectual constructions. The most important indicator, beyond frequency of use, is DESEMANTICIZATION, the process by which the lexical meaning becomes bleached, and the forms in question start to serve functions that are no longer domain-specific (see Traugott \& Heine 1991, Bybee et al. 1994).

The outline of the paper is as follows: We start by introducing the relevant theoretical concepts (section 1.2), followed by the experimental framework (section 1.3) and a description of the morphosyntactic forms in the three languages (section 1.4). Section 2 presents the framework of analysis, section 3 outlines the results of the study, and section 4 discusses the main findings and concludes the analysis. 


\subsection{Defining Progressive Aspect.}

As many theoretical linguists have described the linguistic category of temporal, or viewpoint aspect, there is a large amount of literature on the subject (see, for only a few examples, Comrie 1976, Smith 1991, Bertinetto et al. 2000, Dahl 2000). In the present study, the aspectual viewpoints concern "event is ongoing" and "event is in progress" and how they can be distinguished. In general terms, using Klein's timerelational analysis of aspect (Klein 1994), grammatical aspect relates the topic time of a given situation (time for which an assertion holds) to the situation time (or event time, as it is more commonly referred to in the literature), the unspecified inherent time of the event or situation. For predicates that are explicitly marked for progressive aspect, the "time for which an assertion is made falls entirely within the time of situation. This gives the impression that the situation is seen from the inside" (Klein 1994:108), or in terms of perspective, gives an "inside view" of a particular situation (Comrie 1976:4). Aspectual markers thus defocus the temporal boundaries of a specific situation and express the situation as ongoing at a given time interval (Comrie 1976). An example of a highly grammaticalized progressive aspectual form is the English to be + verbing construction, as in I am writing, which means the event is in progress for the interval asserted. Predicates not marked by progressive morphology can be interpreted as, for example, characterizing habitual events, or general states of individuals that hold for an infinite period of time, as in I write meaning I am a writer (for details see Bybee et al. 1994, Bybee 1994).

We hypothesize that aspectual constructions with a less grammaticalized status than the English progressive, that is, the constructions available in Dutch, Norwegian, and German, are subject to certain constraints that relate to properties of situations, possibly to a different extent in the different languages. In addition to the contexts of use, the question we also seek to answer is whether or not they are adequately described as progressives, and what this term may entail.

\subsection{Previous Empirical Studies of Aspect Marking.}

In the current experimental study, speakers of the three languages were asked to describe the same set of situations presented in short video clips that show everyday events. Each clip showed either a simple event that consisted of a single eventuality, or a short series of interconnected 
events. The situation types have specific properties varied on a systematic basis to focus contexts that may lead to aspectual marking. This means that stimuli were kept constant for all speakers, thereby allowing us to see when event representations overlapped and if differences could be linked to the particular linguistic means of a given language.

Previous studies that used a similar experimental framework focused on the expression of aspect crosslinguistically and its implications for event conceptualization. The studies have covered Romance (French, Italian, Spanish), Semitic (Standard Arabic, Algerian), Slavic (Czech, Russian), and Germanic languages (English, German, Dutch) (see Flecken 2011b, Schmiedtová 2011, von Stutterheim et al. 2012, 2009). Speakers were asked to view video clips showing a vehicle or a person heading toward a possible goal (for example, a bus travelling along a road leading into a town) and describe what was happening. The results show that if the language marks aspect by fully grammaticalized means (imperfective, progressive), speakers are more likely to defocus the goal in that they do not overtly encode it (for example, Standard Arabic, Russian, English). This contrasts with languages without grammatical aspect (for example, German), where the goal of the motion event is overtly mentioned. The results of these experiments are consistent with the description of English, according to which the progressive aspect focuses internal phases of a dynamic situation thereby "defocusing boundaries" (see, for example, Comrie 1976, Dowty 1979).

These studies illustrate what these crosslinguistic differences entail for event conceptualization, using both eye-tracking measures and memory tests. Differences in frequency with which goals are mentioned correlate with fixations on goals shown in the clips, as well as overall performance in remembering them, depending on whether the language encodes aspect or not. Speakers of languages with grammaticalized aspect relate event times to viewing time, which leads to a phasal decomposition of the events (for example, inceptive, intermediate, and terminative phase). In the specific study, this means that goals are not frequently encoded, as they are not part of the intermediate phase of the event actually shown in the clips (that is, the entity moving down/along a particular path). Goals have to be inferred on the basis of the visual input. In contrast, speakers of languages with no grammaticalized aspect do not typically encode subphases of a motion event but represent them 
holistically, with explicitly mentioned goals (for details see von Stutterheim et al. 2012).

Parallel studies within this framework have centered on the concept of progression and how such a notion is expressed in languages with no clearly grammaticalized aspect. The question was whether forms used to describe events as ongoing or in progress would be sensitive to situations that involve actual progressive change. For instance, would they be sensitive to the changes in state of an object in the event of making a model airplane? Situations of this kind show a measurable contrast between the successive stages leading up to the endpoint and the resultant state, that is, the finished object (the model airplane in this example).

The informants' responses are compared with the responses to situations that do not provide a measure for progression, as with activities (Vendler 1957) or one-state situations (Klein 1994), such as jogging or surfing (see, for example, Stutterheim, Carroll \& Klein, 2009). Comparisons of this kind reveal whether nongrammaticalized aspectual forms are more likely to be used if the activity can be viewed as ongoing, without progressive change. As opposed to change-in-state situations with successive stages leading up to an inherent resultant state (for example, an effected object, such as a model airplane), the endpoint or end state of activities is marked by its potential cessation only (for a detailed discussion of aspectual classes and event types see Smith 1991). Furthermore, goal-oriented motion events (for example, walking along a street to a bakery), unlike activities, have a potential directed endpoint, but in contrast to change-in-state situations (for example, building a house) this goal is not inherent. The different situation types are described in more detail in section 2.2 below.

The underlying question in previous studies was as follows: Would situations with a PROGRESSIVE COMPONENT, that is, situations that involve inherent changes in state, be more likely to lead to the use of an aspect marker than the other situation types? It was hypothesized that a "progressive" form should be sensitive to this property. The hypothesis was tested in languages in which use of an aspectual form is optional, such as Italian, French, Spanish, and Dutch. In the Romance languages, aspect marking turned out to be most frequent when informants described change-in-state situations with a progressive component, that is, inherent changes in state of an object. The frequency was lower for situations without a change in state (activities), and even lower (for 
example, in French) for goal-oriented motion events. A similar tendency with respect to motion events was observed in Dutch (see Carroll et al. 2008 for Italian, French, Dutch; Natale 2009 for Italian; Leclerq 2008). In the present study, Dutch is further investigated through a comparison with Norwegian: Dutch and Norwegian, in contrast to the Romance languages, have posture verbs that serve an aspectual function. What properties attract the use of such forms? It should be noted here that when English speakers were asked to view the clips and describe what was happening, they used aspectual marking for all situation types without exception (be $+V$ - ing).

\subsection{Expressing Aspect in Dutch, Norwegian, and German.}

A preliminary study of Dutch and German used the same elicitation procedure as described above and showed differences in explicit aspect marking between the two languages. Flecken (2011a, 2011b) and von Stutterheim et al. (2009) found that the frequency of use of aspectual constructions in German is very low and restricted to only a few types of expressions, such as in 1 .

(1) a. am + VERBAL NOUN sein:

Eine Frau ist am Klavierspielen. a lady is at-the piano play

'A lady is playing the piano.'

b. beim + VERBAL NOUN sein:

Ein Surfer (ist) beim Wellenreiten. a surfer (is) by-the wave-ride

'A surfer is riding the waves.'

c. dabei sein + INF:

Ein Mann ist dabei ein Flugzeug zu falten. a man is there-at a plane to fold 'A man is folding an airplane.'

The constructions in 1a,b involve a prepositional element, an/bei 'at/by', combined with a nominal element - a verbal noun - in contracted form, for example, am (=an dem)/beim (=bei dem) Klavierspielen lit. 'at/by the 
piano-playing'. Clauses with the beim-construction usually show ellipsis of the finite copula. ${ }^{1}$ The construction in 1c involves a pronominal adverb, dabei 'there-at', but it is combined with an infinitival construction with the explicit infinitive particle $z u$ (for a detailed description of all forms, see Ebert 2000, Krause 2002, van Pottelberge 2004). The German forms am and beim occur in their contracted form when marking aspect, for example, Er ist *bei dem Klavierspielen lit. ' $\mathrm{He}$ is at-the piano play'.2

Production data show that the German prepositional constructions do not readily combine with a direct object (von Stutterheim et al. 2009, Flecken 2011b). If they are used in clauses that involve direct objects, the object is usually incorporated into the nominal phrase (as in 1 above: das Klavierspielen lit. 'the piano play'). Such uses, however, are quite rare. These constructions, often called the "Rheinische Verlaufsform", are typical of a specific German regional variant rather than Standard German, (see, for example, van Pottelberge 2004).

A number of empirical findings for Dutch have shown a high frequency of use of the particular construction in $2 \mathrm{a}$, as well as of various constructions with posture verbs, as in 2b-e (see Flecken 2011a).

a. aan het INFINITIVE zijn:

Een mevrouw is een torentje aan het bouwen. a lady is a tower at the build 'A lady is building a tower.'?

\footnotetext{
${ }^{1}$ Van Pottelberge (2004) argues that the beim-construction is more locative in meaning, since clauses with the construction are suitable answers to questions asking for spatial information such as where are you? An appropriate answer would be, for example, Ich bin beim Einkaufen lit. 'I am at-the-shopping'.

${ }^{2}$ Even though the German forms only appear in contraction, when compared to the Dutch aan het-construction they show a much lower degree of flexibility when it comes to object (complement) incorporation and other features of verbal constructions (see van Pottelberge 2004), indicating no signs of grammaticalization.
}

${ }^{3}$ Although the aan het-construction is usually described in the literature as containing an infinitive (see, for example, Boogaart 1999), the presence of the article het 'the' may be taken to indicate that the form is nominal in nature, a verbal noun. In van Pottelberge 2004, however, a number of arguments are put 
b. zitten te INFINITIVE:

Een oudere dame zit een sjaal te breien.

an elderly lady sits a scarf to knit

'A lady is knitting a scarf.'

c. staan te INFINITIVE:

Een man staat te vissen aan de waterkant. a man stands to fish at the waterfront

'A man is fishing at the waterfront.'

d. liggen te INFINITIVE:

Een tablet ligt in een glas te bruisen.

a tablet lies in a glass to fizz

'A tablet is fizzing in a glass of water.'

e. bezig te INFINITIVE:

Een man is bezig een schilderij te maken. a man is busy a painting to make

'A man is painting a picture.'

Construction 2a involves a preposition, aan 'at', plus an infinitive (see, for example, Boogaart 1991, 1999; Ebert 2000; van Pottelberge 2004; Booij 2008), whereas the constructions in $2 b-d$ all involve a posture verb plus an infinitive (for a detailed description, see Lemmens 2005). ${ }^{4}$ The last expression, 2e, consists of the adjective bezig 'busy' plus an infinitive with the infinitive marker te (see, for example, Ebert 2000). All constructions mark verbal aspect and thus explicitly encode the event as ongoing.

forward in favor of labeling the aan het-construction a verbal construction. In line with this analysis, the Dutch construction is considered verbal, as opposed to the German am-construction that is more nominal in nature.

${ }^{4}$ Although the Norwegian posture verb constructions are pseudocoordinations and thus differ from the present Dutch form, it is generally accepted that in Middle Dutch, the posture verb construction was also a pseudocoordination, as in hij zit en leest 'he sits and reads' (Leys 1985). 
The aan het-construction shows the following features with respect to possible syntactic constraints. For example, arguments of the verb can be included within the verb phrase as well as move outside of it, as in 3 .

(3) a. Een meisje is piano aan het spelen. a girl is piano at the play 'A girl is playing the piano.'

b. Een meisje is aan het pianospelen a girl is at the pianoplay 'A girl is playing the piano.'

This pattern shows that the preposition is no longer the obligatory head of a prepositional phrase that includes an object (see Boogaart 1991, van Pottelberge 2004, von Stutterheim et al. 2009), indicating that the function of aan het is no longer that of a locative preposition. Its position close to the verb suggests its increasing grammatical status of a function word. In van Pottelberge 2004, it is argued that the aan het-construction also shares features with other analytical verbal forms, such as the perfect. For example, it is possible to separate the first part of a particle verb, such as inpakken 'to pack', from the aan het phrase, as in 4 . The translation into English would be the same in both cases.

(4) a. Ik ben in aan het pakken.

I am in at the pack

b. Ik ben aan het inpakken.

I am at the inpack

'I am packing.'

Utterances that include a posture verb construction do not allow such flexibility in Dutch. More importantly, the actual posture of an object is still at the core of the choice of a posture verb. Furthermore, the verb phrase can include locative adjuncts, for example, in een stoel 'in a chair', as in 5 .

(5) a. Een vrouw zit een sjaal te breien. a lady sits a scarf to knit

'A lady is knitting a scarf.' 
b. Een vrouw zit in een stoel een sjaal te breien. a lady sits in a chair a scarf to knit 'A lady is in a chair knitting a scarf.'

c. Een vrouw zit een sjaal te breien in een stoel. a lady sits a scarf to knit in a chair 'A lady is knitting a scarf in a chair.'

With respect to Norwegian, to our knowledge there have been no controlled elicitation studies of the use of aspectual constructions. Tonne $(1999,2006,2007)$ divides the available constructions in Norwegian into two subgroups: One type of constructions contains two tensed verbs linked by the coordinator $o g$ 'and', that is, the PSEUDOCOORDINATION, as in sitter og strikker 'sits and knits'. The other type of constructions consists of a tensed verb with a preposition followed by the infinitive, as in holder på a vaske 'holds on to wash'. We present the two structures in turn.

The form of the Norwegian pseudocoordinations parallels the posture verb + infinitive constructions in Dutch, as described above. In both languages, aspect is conveyed by verbs that denote the postures of sitting, standing, and lying, as in 6a-c. Norwegian also has two other pseudocoordinate expressions: One is constructed with the copula vaere 'to be' followed by a locative adverb, as in $6 \mathrm{~d}$ (speaker-oriented, deictic perspective) and the other contains the verb drive (English drive or drift), as in $6 e^{5}$

(6) a. sitter og ...: en dame som sitter og perler et perlekjede sits and ... a lady who sits and pearls a pearl necklace

b. står og ...: Det er ei dame som står og pynter stands and ... It is a lady who stands and decorates

en kake med krem.

a cake with cream

'It's a lady who is decorating a cake with cream.'

${ }^{5}$ See de Groot 2000 for a discussion of the absentive use of this form. 
c. ligger og ...: en røyk som ligger og ryker lies and ... a cigarette which lies and fumes

d. er ute og ...: Her har vi en kvinne som er ute og går. 'is out and ... here have we a woman who is out and walks 'Here's a woman outside walking.'

e. driver og .../(driver på $\mathrm{og} \ldots$...):

drifts and .../(drifts on and..)

en person som driver og hogger ut et ansikt $i$ tre

a person who drifts and carves a face in wood

In the second type of construction, the verb combines with prepositions such as $p a^{\circ}$ 'on', med 'with', til 'to' plus the infinitive of the verb carrying the main lexical content of the sentence. The verb used in each periphrastic form is a word that, when used in other contexts, describes continuity, for example, holde 'to hold', movement, for example, i ferd 'in journey', or path, for example, på vei 'on the way'. Examples are provided in 7 .

(7) a. holder på å ...: en mann som holder på å skjære holds on to ... a man who holds on to carve

ut en trefigur out a wood figure

'A man who is carving a wood figure'

b. er $i$ ferd med $\stackrel{a}{ }$....

is in journey with to ...

et tog som er i ferd med å kjøre a train which is in journey with to drive inn $i$ en tunnel inn $i$ fjellet in to a tunnel in to mountain.the

'A train that is about to enter a tunnel into the mountain' 
c. er på vei til å ...: en røyk som ligger $\mathrm{i}$ et askebeger is on way to to ... a cigarette which lies in an ashtray

\section{og er på vei til å brenne opp \\ and is on way to to burn up}

'A cigarette in an ashtray about to burn out'

d. er i gang med å...: en vaskemaskin som er is in going with to ... a washing machine which is in

gang med å vaske klær

going with to wash clothes

'A washing machine washing clothes'

This latter group of forms has been termed PROSPECTIVE, or the PROSPEC GROUP (Tonne 1999, 2007), as it is held to have two meanings-either the subject referent is in the midst of a situation, or the subject referent is in progress toward a point of change (Tonne 2006:175). In the latter case, the event is seen at a stage before the termination or resultant state, often with the implicature that this resultant state will not obtain.

The pseudocoordinations are viewed as describing a person in the midst of an activity, as in 8 .

(8) En dame sitter og skreller poteter.

a woman sits and peels potatoes

'A woman is peeling potatoes.'

The pseudocoordinations are so named because the apparent coordinated structure (with the conjunction $o g$ 'and') has properties that are more closely connected with the periphrastic form. First of all, the verb in the first conjunct is taken from a restricted set (mainly posture verbs). Furthermore, from a syntactic point of view they have certain properties in common with auxiliaries: In yes/no questions with auxiliaries, for example, the subject must be placed between the auxiliary and the main verb, as in 9a. Example 9b is unacceptable. Pseudocoordinations are 
constrained by the same rule, as exemplified in 10. Regular VP coordination does not behave in this way, as exemplified in 11 .

(9) a. Skal du sole deg?

shall you sunbathe yourself

'Shall you sunbathe?'

b. *Skal sole deg du? shall sunbathe yourself you

(10) a. Sitter du og soler deg? sit you and sunbathe yourself 'Are you sunbathing?'

b. *Sitter og soler deg du? sit and sunbathe yourself you

(11) a. Sover og spiser du hjemme? sleep and eat you at.home 'Do you sleep and eat at home?'

b. *Sover du og spiser hjemme? sleep you and eat at.home

This syntactic difference has been described for Norwegian in Tonne 1999, for Danish in Bjerre \& Bjerre 2007, and for Swedish in Telemann et al. 1999. Norwegian, Swedish, and Danish do not differ on this point.

Another argument that the structure is not a regular VP coordination is that, as observed by Lødrup (2002), it allows a presentational focus construction, as in 12a below. This is unacceptable for a regular VP conjunction, as indicated in $12 \mathrm{~b}$.

(12) a. Det sitter en dame i hagen og soler seg. there sits a lady in garden.the and suntans herself 'There sits a lady in the garden, sunbathing.'

b. *Det sover en mann i hagen og drømmer. there sleeps a man in garden.the and dreams 
Moreover, pseudocoordinations allow an argument of the first verb to appear after the first or after the second verb, as shown in 13.

(13) a. Han står i hagen og glor. he stands in garden.the and gazes

'He is in the garden glaring.'

b. Han står og glor i hagen

he stands and gazes in garden.the

'He is glaring in the garden.'

The locative element is clearly an argument of the first verb: If the first conjunct is omitted, the combination sounds odd, as shown in 14 .

(14) ??Han glor i hagen.

he gazes in garden.the

The syntactic flexibility of locative markers in the posture verb constructions suggests that relative to the second conjunct, the first conjunct has a different status from its counterpart in a true coordination. This is confirmed by an interesting observation related to information structure: The first conjunct can only be assigned a very restricted set of discourse roles, such as background (Kvist-Darnell 2008). This contrasts with true VP coordinations, where the set of discourse relations between the conjuncts is much less restricted. Also, the first conjunct is always unstressed, with the main stress falling on the predicate in the second conjunct. From a semantic point of view, it has been claimed that the meaning of the verb in the first conjunct is somewhat bleached. This has been observed by a number of linguists with respect to pseudocoordination in Scandinavian generally (Vannebo 1969, Tonne 1999 for Norwegian).

In the following we provide a detailed analysis of the frequency of use of the above constructions in German, Norwegian, and Dutch, looking closely at the properties of the different situation types in the experimental design. In doing so, we complement the theoretical analysis of the constructions in Norwegian described above by looking at how they are actually used by native speakers in the current experiment. 


\section{Method.}

\subsection{Participants.}

The Dutch native speaker informants were a group of 32 and a group of 26 students at Radboud University in Nijmegen aged between 18 and 26. The German native speakers were a group of 32 and a group of 20 students at the University of Heidelberg aged between 20 and 35. The Norwegian speakers were a group of 30 and a group of 23 students at the University of Oslo aged between 18 and 29. All groups were balanced for gender. The two groups in each country were recorded on different dates. ${ }^{6}$ Participants were excluded from the sample if their language background questionnaires indicated a long period of residence in an environment where a language other than their mother tongue was spoken or if they were true bilinguals. The data were collected in the respective countries (that is, the Netherlands, Germany, and Norway) by native speaking research assistants.

\subsection{Stimuli.}

The video clips used for the experiment were recordings of real, everyday situations of different types. The situations varied with respect to specific properties that were deemed relevant for the crosslinguistic comparison. The properties listed below do not relate to the linguistic expressions used to describe them. The stimuli covered six different situation types (see tables 1 and 2 for a full list of all critical items).

The categorization of the various situation types was based on the properties of real-world situations, irrespective of the language and potential classical categorization of the predicates used by our informants. As mentioned above, these properties were systematically manipulated in the experiment in order to investigate the extent to which

\footnotetext{
${ }^{6}$ For each language, two data sets were recorded. They were put together for the analysis of overall frequency of progressive marking regardless of the situation type. Both data sets were elicited under the exact same conditions, following the same experimental procedure. The first group of speakers of each language verbalized events on the basis of stimuli of situation types 1, 2, 4, and a set of distracter items. The second group of speakers verbalized events depicted in stimuli of situation type 3 , plus a set of distracter items. In both experiments, situation types were pseudo-randomized and distracter items were embedded in the stimulus sets (there were thus more distracter items in the second stimulus set).
} 
they may promote or constrain the use of aspectual constructions in each language. All video clips depict the same phase, that is, the intermediate phase of the situations. The change-in-state situations show the creation of an object with an inherent endpoint, for example, making a model airplane or knitting a scarf (type 1). The relevant factor in testing the status of the term progressive is that these situations show a perceptible contrast between the successive states leading up to the finished object, or the inherent endpoint of the event. In this sense, they provide a measure for progression and have a progressive component. They serve the purpose of testing its relevance for the use of aspectual constructions in the three languages.

\begin{tabular}{|c|c|c|c|c|c|c|}
\hline \multirow{2}{*}{\multicolumn{2}{|c|}{$\begin{array}{l}\text { Type } 1 \\
\text { Change-in-state } \\
\text { situation }\end{array}$}} & \multirow{3}{*}{$\begin{array}{l}\text { Type } 2 \\
\text { Change- } \\
\text { in-state } \\
\text { situations }\end{array}$} & \multirow{3}{*}{$\begin{array}{l}\text { Type } 3 \\
\text { Situations } \\
\text { with no } \\
\text { change in } \\
\text { state }\end{array}$} & \multicolumn{2}{|c|}{ Type 4} & \multirow[t]{3}{*}{ Fillers } \\
\hline & & & & Motion e & & \\
\hline $\begin{array}{l}\text { effected } \\
\text { object }\end{array}$ & $\begin{array}{l}\text { affected } \\
\text { object }\end{array}$ & & & $\begin{array}{l}\text { goal not } \\
\text { reached }\end{array}$ & $\begin{array}{l}\text { goal } \\
\text { reached }\end{array}$ & \\
\hline $\begin{array}{l}\text { Change } \\
\text { in state of } \\
\text { object } \\
\text { (creation) } \\
\text { as } \\
\text { inherent } \\
\text { endpoint }\end{array}$ & $\begin{array}{l}\text { Change } \\
\text { in state } \\
\text { of object } \\
\text { (transfor- } \\
\text { mation) } \\
\text { as } \\
\text { inherent } \\
\text { endpoint }\end{array}$ & $\begin{array}{l}\text { Change in } \\
\text { state of } \\
\text { object } \\
\text { (non } \\
\text { existence) } \\
\text { as } \\
\text { inherent } \\
\text { endpoint }\end{array}$ & $\begin{array}{l}\text { Cessation } \\
\text { of activity } \\
\text { as } \\
\text { endpoint } \\
\text { (no } \\
\text { inherent } \\
\text { endpoint) }\end{array}$ & $\begin{array}{l}\text { Change } \\
\text { in place } \\
\text { (person } \\
\text { vehicle) } \\
\text { goal not } \\
\text { evident }\end{array}$ & $\begin{array}{l}\text { Change } \\
\text { in place } \\
\text { (person } \\
\text { vehicle) } \\
\text { goal } \\
\text { evident }\end{array}$ & $\begin{array}{l}\text { Object at } \\
\text { place; } \\
\text { Object } \\
\text { changing } \\
\text { place }\end{array}$ \\
\hline $\begin{array}{l}9 \text { video } \\
\text { clips }\end{array}$ & $\begin{array}{l}5 \text { video } \\
\text { clips }\end{array}$ & $\begin{array}{l}5 \text { video } \\
\text { clips }\end{array}$ & $\begin{array}{l}9 \text { video } \\
\text { clips }\end{array}$ & $\begin{array}{l}12 \text { video } \\
\text { clips }\end{array}$ & $\begin{array}{l}12 \text { video } \\
\text { clips }\end{array}$ & $\begin{array}{l}14 \text { video } \\
\text { clips }\end{array}$ \\
\hline $\begin{array}{l}\text { a woman } \\
\text { building } \\
\text { a house } \\
\text { of cards }\end{array}$ & $\begin{array}{l}\text { a man } \\
\text { peeling a } \\
\text { potato }\end{array}$ & $\begin{array}{l}\text { a candle } \\
\text { burning } \\
\text { down }\end{array}$ & $\begin{array}{l}\text { a man } \\
\text { jogging }\end{array}$ & $\begin{array}{l}\text { a car } \\
\text { driving } \\
\text { down the } \\
\text { road (to } \\
X)\end{array}$ & $\begin{array}{l}\text { a dog } \\
\text { running } \\
\text { into a } \\
\text { house }\end{array}$ & $\begin{array}{l}\text { news- } \\
\text { paper } \\
\text { floating } \\
\text { across a } \\
\text { street }\end{array}$ \\
\hline
\end{tabular}

Table 1. Situation types represented in the stimulus set.

Situations that belong to this type also contrast with respect to dynamicity. Situations that involve highly dynamic changes are contrasted with situations in which the change of state is less dynamic and less 
perceptible. The highly dynamic situations all involve an agent acting on an object, that is, an agent in the process of creating a particular object (a model airplane) - an effected object. The second group within this category contains change-in-state situations that also involve an affected object but do not involve creation; instead, they involve a transformation of an object (for instance, decorating a cake). The resultant state is the existence of the effected object or the final transformed state of the affected object.

In the change-in-state situations with low dynamicity (type 2), the change is not salient, and it takes place at a slower rate compared to type 1 situations. They range from a pill dissolving in water, with a slow conversion to a resulting liquid state, a cigarette burning and slowly turning to ash, to someone sitting on a bench sunbathing, with a tan in some form as the resultant state. Although there are inherent differences in the natural duration of the eventualities that make up different situation types - for example, a pill dissolves in water faster than a candle burns down - they all share the core feature of having low dynamicity. In contrast to type 1 , the initiator of the change in state is invisible in all cases (the person who lit the cigarette or candle, for example, is not shown).

Situations that belong to type 3 involve no change in state; they involve activities - sports or games, such as someone fishing, jogging, swimming, or playing the violin. No inherent change on the part of the event participant is implied with situations of this kind. As opposed to the change-in-state situations, where changes lead to the creation of an object (the inherent endpoint), the contrast between the activity and its potential endpoint is minimal in the sense that the endpoint coincides with the cessation of the activity (Smith 1991). This situation type does not provide any inherent measure for progression in the form of changes in state of an object. In this sense, situations involving activities can be viewed as displaying a high level of continuity of the activity depicted in the clips (one can jog in circles in a gym, for example, and stop at any point). These situations all involve an active participant, and due to this property - that is, continuity-in the present framework they served to test the use of aspect markers.

Situations that belong to type 4 include motion events that involve a change in place of a person, vehicle, or animal moving along a path from point A to B. They cover two groups of events that differ with respect to 


\section{Behrens, Flecken, and Carroll}

the goal: a) situations in which the goal is actually reached by the moving entity during the time span of the video clip (for example, a car driving into a garage, a girl running to the train station and entering through the main door), and b) situations in which the entities in motion do not reach the potential goal, and the path is focused (for example, two girls walking along a path in the direction of a house). The motion events differ from activities in that they are goal-oriented in space, which does not apply to activities. The potential goal is not inherent, in contrast to the change-in-state situations (type 1).

The final factor concerns the role of HOMOGENEITY, that is, the degree to which the situation depicted consists of subparts that are similar and repetitive in nature. If the clip depicts an event of molding a vase on a potter's wheel, for example, the action is homogeneous in that the same procedure of smoothing the surface by hand is repeated through the entire scene. In a heterogeneous situation, in contrast, the subparts represent distinct individual steps, as, for example, in the event of folding a paper airplane. This distinction is a matter of degree, which means that not all the situations are clearly one or the other. A subset of items showing a change in state was designed to test the role of this feature (see table 2 below).

It is important to bear in mind that the classification above makes no claims as to how speakers of different languages would actually describe these situations. Our focus, as mentioned above, is on comparing the frequency with which speakers use aspectual constructions in their responses and how this frequency correlates with the properties presented. The stimuli are listed in the following overview (types 1 and 3 are listed first, with their classification with respect to homogeneity and position of actors).

The video clip eventualities listed in table 2 below were used in our experiment and analyzed according to the properties distinguished here. 


\begin{tabular}{|c|c|c|}
\hline $\begin{array}{l}\text { Type } 1 \\
\text { Change-in-state situations } \\
\text { - effected object }(\mathrm{N}=9)\end{array}$ & $\begin{array}{l}\text { Type } 1 \\
\text { Change-in-state } \\
\text { situations } \\
\text { - affected object }(\mathrm{N}=5) \\
\end{array}$ & $\begin{array}{l}\text { Type } 3 \\
\text { No change-in-state } \\
\text { situations } \\
(\mathrm{N}=9) \\
\end{array}$ \\
\hline $\begin{array}{l}\text { woman beading a necklace } \\
\text { resultant state: necklace } \\
\text { - heterogeneous events } \\
\text { (sitting) }\end{array}$ & woman decorating a cake & people playing table tennis \\
\hline $\begin{array}{l}\text { woman building a house of } \\
\text { cards } \\
\text { - heterogeneous events } \\
\text { (sitting) }\end{array}$ & $\begin{array}{l}\text { man sweeping the } \\
\text { sidewalk } \\
\text { (standing- } \\
\text { moving-standing) }\end{array}$ & women playing cards \\
\hline $\begin{array}{l}\text { man making a figure out of } \\
\text { plasticine } \\
\text { - heterogeneous events } \\
\text { (sitting) }\end{array}$ & (standing) & (standing) \\
\hline $\begin{array}{l}\text { man folding a paper } \\
\text { airplane } \\
\text { - heterogeneous events } \\
\text { (sitting) }\end{array}$ & man peeling potatoes & (standing) \\
\hline $\begin{array}{l}\text { woman building tower of } \\
\text { blocks } \\
\text { - heterogeneous events } \\
\text { (sitting) }\end{array}$ & woman shredding paper & $\begin{array}{l}\text { conductor conducting an } \\
\text { orchestra } \\
\text { (standing) }\end{array}$ \\
\hline $\begin{array}{l}\text { man drawing a tree and } \\
\text { shown shading in the trunk } \\
\text { - homogeneous events } \\
\text { (sitting) }\end{array}$ & & woman playing an organ \\
\hline $\begin{array}{l}\text { woman knitting a scarf } \\
\text { - homogeneous events } \\
\text { (sitting) }\end{array}$ & & $\begin{array}{l}\text { woman playing a violin } \\
\text { (standing) }\end{array}$ \\
\hline $\begin{array}{l}\text { woman painting a picture } \\
\text { - homogeneous events } \\
\text { (sitting) }\end{array}$ & & $\begin{array}{l}\text { man surfing } \\
\text { (moving) }\end{array}$ \\
\hline $\begin{array}{l}\text { man molding a vase } \\
\text { - homogeneous events } \\
\text { (sitting) }\end{array}$ & & $\begin{array}{l}\text { woman jogging } \\
\text { (moving) }\end{array}$ \\
\hline
\end{tabular}




\begin{tabular}{|c|c|c|}
\hline $\begin{array}{l}\text { Type } 4 \\
\text { Motion events } \\
\text { - endpoint not reached } \\
(\mathrm{N}=12)\end{array}$ & $\begin{array}{l}\text { Type } 4 \\
\text { Motion events } \\
\text { - endpoint reached } \\
(\mathrm{N}=12)\end{array}$ & $\begin{array}{l}\text { Type } 2 \\
\text { Change-in-state } \\
\text { situations } \\
\text { - low level of dynamicity } \\
(\mathrm{N}=5)\end{array}$ \\
\hline $\begin{array}{l}\text { car driving along a road } \\
\text { (toward a house) }\end{array}$ & car driving into a garage & pill dissolving in water \\
\hline $\begin{array}{l}\text { woman walking across a } \\
\text { parking lot (toward a car) }\end{array}$ & girl entering the station & $\begin{array}{l}\text { cigarette in an ashtray } \\
\text { burning }\end{array}$ \\
\hline $\begin{array}{l}\text { woman walking along the } \\
\text { street (toward a barrier) }\end{array}$ & $\begin{array}{l}\text { van turning into a } \\
\text { driveway }\end{array}$ & candle burning \\
\hline $\begin{array}{l}\text { girl cycling on a path } \\
\text { (toward a house) }\end{array}$ & $\begin{array}{l}\text { man on a bicycle turning } \\
\text { into a gateway }\end{array}$ & woman sunbathing \\
\hline $\begin{array}{l}\text { boy walking on a path } \\
\text { (toward a playground) }\end{array}$ & $\begin{array}{l}\text { woman entering a } \\
\text { supermarket }\end{array}$ & water running from a tap \\
\hline $\begin{array}{l}\text { man climbing a ladder } \\
\text { (toward a balcony) }\end{array}$ & $\begin{array}{l}\text { dog running through the } \\
\text { door of a building }\end{array}$ & $\begin{array}{l}\text { Filler Items - no changes } \\
\text { in state; main referent } \\
\text { not human }(N=14)\end{array}$ \\
\hline $\begin{array}{l}\text { man crossing a street } \\
\text { (toward a car) }\end{array}$ & $\begin{array}{l}\text { cat walking into the } \\
\text { kitchen }\end{array}$ & $\begin{array}{l}\text { newspaper floating across } \\
\text { a street } \\
\text { barrier closing }\end{array}$ \\
\hline $\begin{array}{l}\text { girls walking along a path } \\
\text { (toward a house) }\end{array}$ & $\begin{array}{l}\text { child going through a } \\
\text { gate into a playground }\end{array}$ & $\begin{array}{l}\text { leaves floating in a pond } \\
\text { traffic lights on the blink }\end{array}$ \\
\hline $\begin{array}{l}\text { girl riding a horse } \\
\text { (toward a gate) }\end{array}$ & $\begin{array}{l}\text { man walking into a } \\
\text { church }\end{array}$ & $\begin{array}{l}\text { key being turned in a lock } \\
\text { bird flapping its wings }\end{array}$ \\
\hline $\begin{array}{l}\text { girls walking through a } \\
\text { park (toward a bench) }\end{array}$ & $\begin{array}{l}\text { girl riding a horse into a } \\
\text { barn }\end{array}$ & $\begin{array}{l}\text { ball bouncing across a } \\
\text { yard } \\
\text { pendulum swinging back } \\
\text { and forth }\end{array}$ \\
\hline $\begin{array}{l}\text { car driving along a road } \\
\text { (toward a petrol station) }\end{array}$ & $\begin{array}{l}\text { woman on a bicycle } \\
\text { turning into a forest }\end{array}$ & $\begin{array}{l}\text { bike parked at a lamp post } \\
\text { dog barking }\end{array}$ \\
\hline $\begin{array}{l}\text { man rowing down a river } \\
\text { (toward the pier) }\end{array}$ & train going into a tunnel & $\begin{array}{l}\text { horse standing in a field } \\
\text { flags flattering in the wind } \\
\text { kettle boiling } \\
\text { clothes spinning in a } \\
\text { washing machine }\end{array}$ \\
\hline
\end{tabular}

Table 2. All stimuli with event features. 


\subsection{Experimental Procedure.}

The stimulus set consisted of 66 video clips, depicting the six situation types described above (see table 2) and 14 filler items. They were presented in two pseudo-randomized lists to which subjects in all languages were assigned in a sequential order (this means that the first Dutch, German, and Norwegian participant performed the task with pseudo-randomized list 1, participant 2-with list 2, participant 3 watched list 1 , etc.). All participants were told that they would see a set of video clips showing different everyday situations not connected in any way, and that their task was to view each clip and describe what was happening (in Dutch: Het is uw opgave om te vertellen wat er gebeurt; in German: Es ist Ihre Aufgabe, zu sagen was passiert; in Norwegian: Du skal bare fortelle hva som skjer).

The participants were explicitly told to focus on the event only and not to give a detailed description of the scene (colors, clothing). It was emphasized that the focus of the study was the domain of events and the use of verb forms. The participants were also told that they could start describing each event as soon as they recognized what was happening. Following the experiment, which took approximately 15 minutes, they were asked to fill out a questionnaire concerning their linguistic and educational background.

\section{Overall Results.}

The figures presented in the analyses below are based on occurrences of the aspectual constructions described in section 1.4. The three languages differ with respect to the frequency with which the constructions are used, with Dutch ranking highest, German lowest, and Norwegian in between the two.

\begin{tabular}{ccc}
\hline Dutch & Norwegian & German \\
\hline $443 / 1610$ & $217 / 1497$ & $22 / 1556$ \\
$27.52 \%$ & $14.50 \%$ & $1.41 \% 2.05 \%$ \\
\hline
\end{tabular}

Table 3. Overall frequency of use of aspectual constructions (as a percentage of the total number of utterances for all critical stimuli). ${ }^{7}$

\footnotetext{
${ }^{7}$ Note that in table 3 and in the statistical analysis of total frequency of progressive marking, the data from the two groups of participants for each language
} 


\section{Behrens, Flecken, and Carroll}

A two-tailed z-test for comparing the proportion of aspectual constructions in Dutch and Norwegian gives a significant difference $(\mathrm{z}=8.822, \mathrm{p}<.05)$. The difference between Dutch and German is also significant $(\mathrm{z}=20.699, \mathrm{p}<.05)$, as is the difference between German and Norwegian $(z=13.393, p<.05)$. Table 4 and figure 1 below show the frequency with which these constructions occur per situation type.

A closer look at the extent to which speakers mark aspect across the six different situation types reveals distinct patterns of use in the three languages: In Dutch, change-in-state situations with an inherent endpoint in the form of an effected or affected object (that is, with a progressive component), as well as situations with no change in state show similar rates of occurrence (the difference is not significant: $\mathrm{z}=0.774$, n.s.). Situations with low dynamicity (for example, a candle burning) as well as motion events are comparably much weaker attractors.

In Norwegian, the frequency of use of aspectual constructions - in this case posture verbs - is low in overall terms $(14.50 \%)$. There is a clear preference for situations without a change in state (activities). Frequencies drop significantly once a change in state is involved (activities versus change-in-state situations with an effected object: $\mathrm{z}=3.977, \mathrm{p}<.05$ ). There is no significant difference in frequency between the situations with high and low dynamicity: The frequency of use is equally low for situations that involve a change in state, an effected object and high dynamicity, and situations that involve a change in state and low dynamicity ( $\mathrm{z}=0.558$, n.s.).

In contrast to Dutch and Norwegian, the overall percentage for German is very low, and thus unreliable. For the few cases observed, aspectual constructions are more likely to be used to describe situations showing no change in state. A final observation for all three languages is that for motion events with a potential goal, no occurrences of aspect

have been grouped together and totaled. The number of participants in each of the two groups varies from language to language: Dutch group $1 \mathrm{~N}=32$, group 2 $\mathrm{N}=26$; Norwegian group $1 \mathrm{~N}=30$, group $2 \mathrm{~N}=23$; German group $1 \mathrm{~N}=32$, group $2 \mathrm{~N}=20$. This leads to the different total number of utterances in the three languages. All groups were balanced for age and gender, and given the exact same experimental setup and instructions, which, in our opinion, justifies the clustering of data from two different participant groups in this particular analysis. 
marking were observed, irrespective of whether the goal was reached or not. The same constraint has also been observed for French (Leclerq 2008). The next sections take a closer look at the contexts in which the different forms in Dutch, Norwegian, and German were typically used.

\begin{tabular}{|c|c|c|c|c|c|c|}
\hline & \multirow[t]{2}{*}{$\begin{array}{l}\text { No } \\
\text { change } \\
\text { in state }\end{array}$} & \multicolumn{2}{|c|}{$\begin{array}{l}\text { Change in state: } \\
\text { high } \\
\text { dynamicity }\end{array}$} & \multirow[t]{2}{*}{$\begin{array}{l}\text { Change in } \\
\text { state: low } \\
\text { dynamicity }\end{array}$} & \multicolumn{2}{|c|}{ Motion events } \\
\hline & & $\begin{array}{l}\text { effected } \\
\text { object }\end{array}$ & $\begin{array}{l}\text { affected } \\
\text { object }\end{array}$ & & $\begin{array}{l}\text { endpoint } \\
\text { not } \\
\text { reached }\end{array}$ & $\begin{array}{l}\text { endpoint } \\
\text { reached }\end{array}$ \\
\hline Dutch & $\begin{array}{l}154 / 234 \\
\mathbf{6 5 . 8 1 \%}\end{array}$ & $\begin{array}{l}179 / 288 \\
\mathbf{6 2 . 1 5 \%}\end{array}$ & $\begin{array}{l}84 / 160 \\
\mathbf{5 2 . 5 \%}\end{array}$ & $\begin{array}{l}19 / 160 \\
11.88 \%\end{array}$ & $\begin{array}{l}7 / 384 \\
1.82 \%\end{array}$ & $\begin{array}{l}0 / 384 \\
0 \%\end{array}$ \\
\hline Norwegian & $\begin{array}{l}80 / 207 \\
\mathbf{3 8 . 6 5 \%}\end{array}$ & $\begin{array}{l}59 / 270 \\
\mathbf{2 1 . 8 5 \%}\end{array}$ & $\begin{array}{l}13 / 150 \\
8.7 \%\end{array}$ & $\begin{array}{l}28 / 150 \\
\mathbf{1 8 . 6 7 \%}\end{array}$ & $\begin{array}{l}17 / 360 \\
4.72 \%\end{array}$ & $\begin{array}{l}20 / 360 \\
5.56 \%\end{array}$ \\
\hline German & $\begin{array}{l}17 / 180 \\
9.44 \%\end{array}$ & $\begin{array}{l}4 / 288 \\
1.39 \%\end{array}$ & $\begin{array}{l}1 / 160 \\
0.63 \%\end{array}$ & $\begin{array}{l}0 / 160 \\
0 \%\end{array}$ & $\begin{array}{l}0 / 384 \\
0 \%\end{array}$ & $\begin{array}{l}0 / 384 \\
0 \%\end{array}$ \\
\hline
\end{tabular}

Table 4. Use of aspectual constructions per situation type (frequency of use as a percentage of all utterances for the situation type).

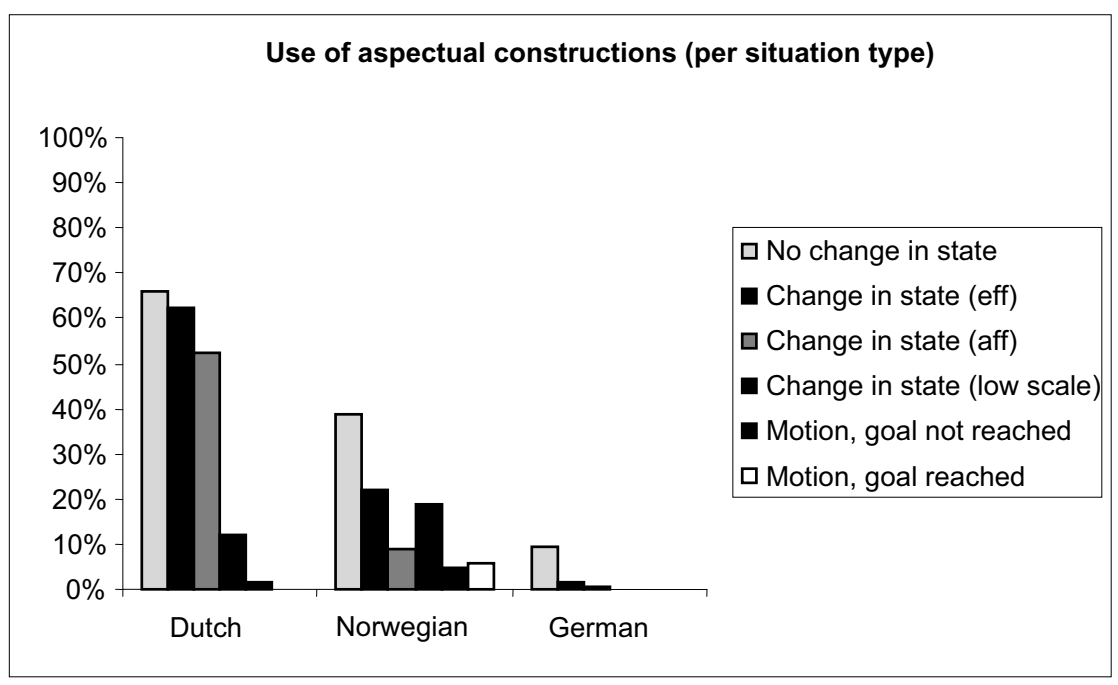

Figure 1. Aspectual constructions for the different situation types in the three languages. 


\section{Behrens, Flecken, and Carroll}

\section{Dutch: Frequency of Use and Qualitative Analysis.}

With an overall frequency of use at $27.52 \%$ (see table 3 ), the distribution of the different aspect markers in Dutch is depicted in table 5. We observed that when an aspect marker was chosen, the aan hetconstruction was preferred over others across the board (375 out of the total 443 aspectual constructions used, or $84.65 \%$ ).

\begin{tabular}{|c|c|c|c|c|c|c|}
\hline $\begin{array}{l}\text { Situation } \\
\text { type }\end{array}$ & $\begin{array}{l}\text { aan het } X \\
\text { zijn }\end{array}$ & $\begin{array}{l}\text { zitten te } \\
+\mathrm{V} \text {-inf }\end{array}$ & $\begin{array}{l}\text { liggen te } \\
+\mathrm{V} \text {-inf }\end{array}$ & $\begin{array}{l}\text { staan te } \\
+\mathrm{V} \text {-inf }\end{array}$ & $\begin{array}{l}\text { bezig te } \\
+\mathrm{V} \text {-inf }\end{array}$ & Total \\
\hline $\begin{array}{l}\text { Situations } \\
\text { no change } \\
\text { in state }\end{array}$ & $\begin{array}{l}116 / 234 \\
49.57 \%\end{array}$ & $\begin{array}{l}22 / 234 \\
9.40 \%\end{array}$ & $\begin{array}{l}6 / 234 \\
2.56 \%\end{array}$ & $\begin{array}{l}10 / 234 \\
4.27 \%\end{array}$ & 0 & $\begin{array}{l}154 \\
(/ 234)\end{array}$ \\
\hline $\begin{array}{l}\text { Change in } \\
\text { state: } \\
\text { effected }\end{array}$ & $\begin{array}{l}161 / 288 \\
55.90 \%\end{array}$ & $\begin{array}{l}12 / 288 \\
4.17 \%\end{array}$ & 0 & 0 & $\begin{array}{l}6 / 288 \\
2 \%\end{array}$ & $\begin{array}{l}179 \\
(/ 288)\end{array}$ \\
\hline $\begin{array}{l}\text { Change in } \\
\text { state: } \\
\text { affected }\end{array}$ & $\begin{array}{l}79 / 160 \\
49.38 \%\end{array}$ & $\begin{array}{l}2 / 160 \\
1.25 \%\end{array}$ & 0 & 0 & $\begin{array}{l}3 / 160 \\
1.88 \%\end{array}$ & $\begin{array}{l}84 \\
(/ 160)\end{array}$ \\
\hline $\begin{array}{l}\text { Change in } \\
\text { state: low } \\
\text { scale }\end{array}$ & $\begin{array}{l}12 / 160 \\
7.50 \%\end{array}$ & $\begin{array}{l}1 / 160 \\
0.63 \%\end{array}$ & $\begin{array}{l}5 / 160 \\
3.13 \%\end{array}$ & $\begin{array}{l}1 / 160 \\
0.63 \%\end{array}$ & 0 & $\begin{array}{l}19 \\
(/ 160)\end{array}$ \\
\hline $\begin{array}{l}\text { Motion } \\
\text { events - EP } \\
\text { not reached }\end{array}$ & $\begin{array}{l}7 / 384 \\
1.82 \%\end{array}$ & 0 & 0 & 0 & 0 & $\begin{array}{l}7 \\
(/ 384)\end{array}$ \\
\hline $\begin{array}{l}\text { Motion } \\
\text { events - EP } \\
\text { reached }\end{array}$ & 0 & 0 & 0 & 0 & 0 & $\begin{array}{l}\mathbf{0} \\
(/ 384)\end{array}$ \\
\hline Total & $375 / 1610$ & $37 / 1610$ & $11 / 1610$ & $11 / 1610$ & $9 / 1610$ & \\
\hline
\end{tabular}

Table 5. Types of aspectual constructions in the Dutch data (frequency of use as a percentage of all utterances for the situation type).

The results reveal, as mentioned above, that in Dutch-but not in Norwegian and German-situations involving a change in state are as likely to lead to the use of aspectual forms as activities. The findings for Dutch pattern, to a certain extent, with those for the Romance languages Italian and French, although in these languages, the overall occurrence of aspectual forms is higher for change-in-state situations than for activities. 
The overall occurrence of aspectual constructions across all situation types is also higher in Italian and French than in Dutch (see section 1.3 above).

With regard to the relevance of homogeneity for the use of aspectual markers, in Dutch $62.15 \%$ of change-in-state situations with an effected object were described using aspectual markers. Within this group of stimuli, the descriptions of scenes with homogeneous events showed the highest occurrence of aspectual marking: painting a picture (27 out of 32 responses were marked for aspect, or $84.37 \%$ ); knitting a scarf (21 out of 32 responses, or $65.62 \%$ ); molding a vase (27 out of 32 responses, or $84.37 \%$ ). The rate was lower in the descriptions of scenes with heterogeneous events: making a figure out of plasticine (15 out of 32, or $46.87 \%$ ); folding an airplane (15 out of 32 , or $46.87 \%$ ); building a house of cards (12 out of 32 , or $37.50 \%$ ). In sum, highly dynamic change-instate situations with homogeneous events were more likely to lead to the use of aspectual constructions than the other situation types.

\subsection{Posture Verbs or Aan Het?}

At this point, we present a detailed analysis of the forms used to mark aspect in the Dutch data. Posture verbs account for 38 out of 154 expressions (24.68\%), while the aan het-construction occurs in the majority of utterances (116 out of 154 responses, or $75.32 \%$ ). A closer look at the distribution of posture verbs and the aan het-construction indicates that the latter is significantly more likely to occur with changein-state situations: 161 out of 173 , or $93.06 \%$. The aan het-construction was used even when the scene showed a person either sitting or standing, that is, in cases when a posture verb construction would be appropriate, in theory at least. In cases when a posture verb was selected, there was always a connection between the semantics of the posture verb and the posture shown in the video clip. The scene described in 15a involves an agent who is clearly sitting; in $15 \mathrm{~b}$, the street musicians in the scene are standing.

(15) a. Een vrouw zit kralen te rijgen a lady sits beads to thread 
aan een draad voor een ketting.

on a string for a necklace

'A lady is threading beads on a string for a necklace.'

b. Twee mensen staan op straat muziek te maken. two persons stand on street music to make 'Two persons are making music on the street.'

To sum up this section, Dutch speakers show clear preferences in the selection of means of aspect expression when describing the situation types studied. Compared to the occurrence of the aan het-construction, the occurrence of posture verbs in this task is low. The grammatical nature of the aan het-construction is underlined by the fact that the occurrence of posture verbs is significantly lower than one would expect based on the content of the scenes (the participants in the change-in-state situations, for example, are all sitting). Although posture verbs were used in descriptions of all situation types, they were clearly superseded by the aan het-construction in rate of occurrence. However, neither construction has yet developed to accommodate change-in-place situations with directed motion toward a potential goal, as shown by the very low occurrence of either construction in descriptions of goal-oriented motion events (only 1.82\%). Although this is a very different case from the highly grammaticalized progressive form in English, the overall preference for the aan het-construction, along with morphosyntactic features and the lack of dependency on features such as posture, indicate that this form is more grammaticalized than the posture verb constructions in Dutch.

\section{Norwegian: Frequency of Use and Qualitative Analysis.}

The distribution of the different constructions used in Norwegian is listed in table 6 below. Aspectual constructions occur in only $14.5 \%$ of all utterances. Starting with the means of expression, we note that the Norwegian pseudocoordinations largely parallel the Dutch posture verb constructions in form (see section 1.4 above). We observed that the pseudocoordinate structure was preferred over the prospec forms, regardless of whether the scene involved a change in state or not (189 out of 1497 , or $12.6 \%)$. The prospec forms are very infrequent in the data (28 
out of 1497 , or $1.9 \%$ of the total number of utterances). The low frequency of their use could confirm Tonne's conclusion (see 2.2 above) that they often involve an implicature of an unattained result (for example, er på vei til å.... en røyk som ligger $i$ et askebeger og er på vei til a brenne opp lit. 'is on way to... a cigarette which lies in an ashtray and is on way to burn out'). We would need more complex scenes demanding longer narratives to assess the use of the prospec forms beyond the present experiment. However, the variety of forms used overall is interesting and is considered again in section 7.

The two most frequent expressions are posture verb constructions with the verbs stand and sit. Their distribution across the situation types was conditioned by the posture of the characters in the scene. Half of the video clips that depicted situations with no change of state actually showed the character in a standing position (fishing). In descriptions of such situations, the posture verb construction with stå 'stand' appeared with the highest frequency $(18.22 \%)$. In contrast, video clips that depicted change-in-state situations with an effected object showed the agent/ actor in a sitting position, and the occurrence of the posture verb sit in this case was at $17.41 \%$.

The data thus confirm that there is still a close connection between the posture verb chosen and the posture of the characters in the scenes. This explains the infrequency of ligger og 'lies and', as the scenes very seldom depicted a situation involving a lying position. We conclude that the posture verb constructions retain much of their lexical meaning and are therefore chosen depending on the actual posture in the video clip. They are not, however, restricted to truly agentive actions. The changein-state situations with low dynamicity mainly have inanimate subjects (see 2.1, a pill is dissolving, a candle is burning), but this does not rule out the use of posture verb constructions.

Having compared the use of the Norwegian posture verb constructions with the use of their counterparts in Dutch, we found a significantly higher frequency of use in Norwegian. The Norwegian nonposture verb structures do not come anywhere near the Dutch aan het-construction in terms of frequency of use. Another notable observation is that the locative constructions på vei 'on the way' and (to some extent) ute og 'out and' are mainly used in motion events (with or without a goal). This may be related to the lexical content of the construction: på vei 'on the way' has a strong directional change-of-place 


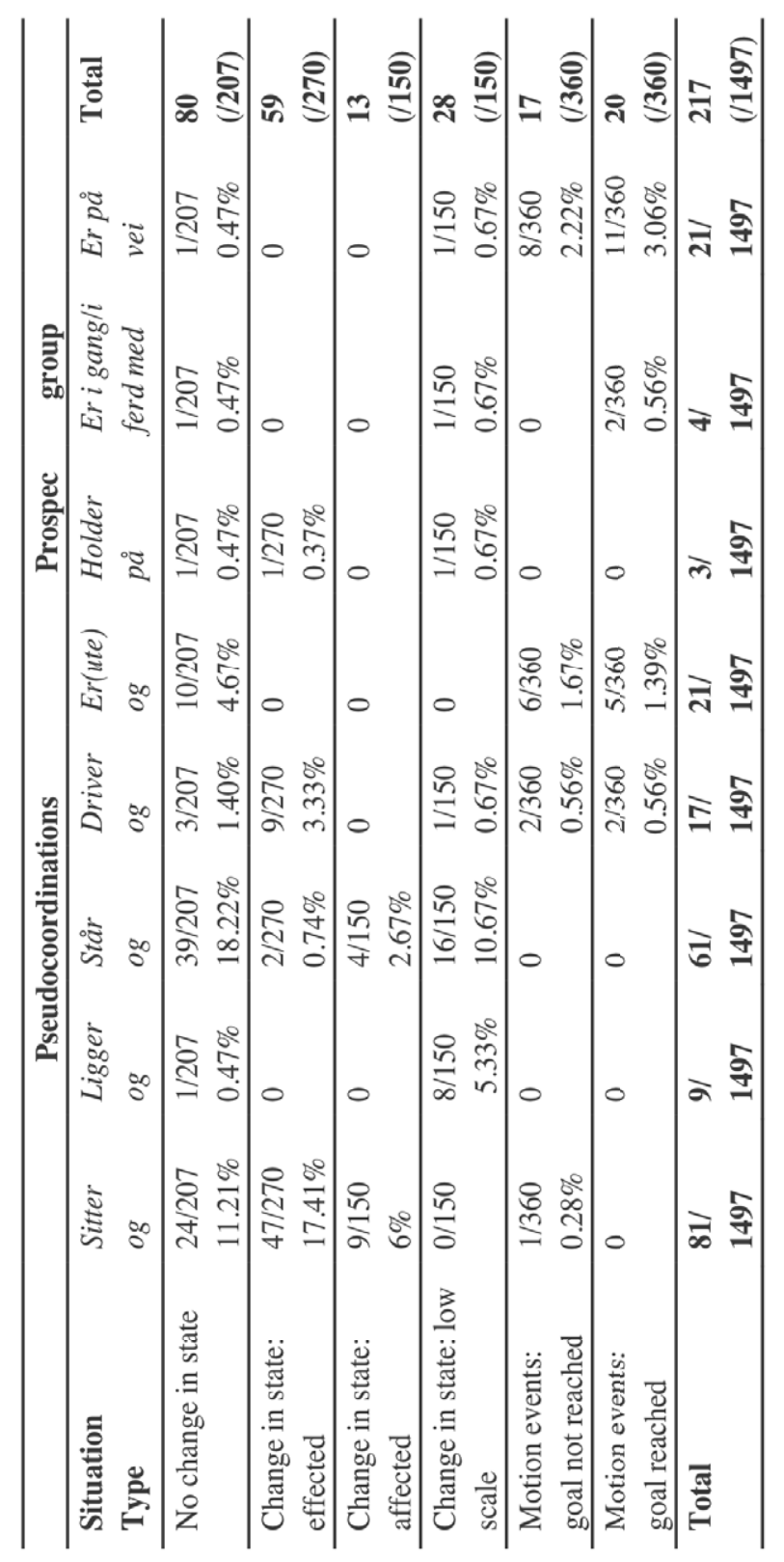

Table 6. Types of constructions used in the Norwegian data 
(frequency of use as a percentage of all utterances for the situation type). component. In comparison to Dutch and German, Norwegian is unique in having specific forms to mark aspect in motion events, even if their use is infrequent.

As for Dutch, we now discuss the use of all aspectual constructions across situation types, including the role of the homogeneity factor. All occurrences in change-in-state situations, including those with an effected object, amounted to 59 out of a total of 270 responses $(21.85 \%)$. Within this situation type, scenes with highly homogeneous events display the highest rate of occurrence, for example, knitting a scarf (19 out of 30 responses, or $63.3 \%$ ), painting a picture (12 out of 30 responses, or $40 \%$ ), which corresponds to the findings in Dutch. The rate of occurrence drops considerably in descriptions of scenes with heterogeneous events, for example, building a house of cards (3 out of 30 responses, or $10.0 \%$ ), folding a paper airplane (4 out of 30 responses, or $13.3 \%$ ), or beading a necklace (5 out of 30 responses, or $16.6 \%$ ). The occurrence of aspectual constructions in scenes with heterogeneous events is low by comparison.

Compared to the situations with no change of state, that is, activities such as playing cards or playing piano, aspectual constructions occur in 80 out of 207 utterances (38.65\%). The particular use of aspectual constructions with respect to this situation type also supports the homogeneity effect: Situations with homogeneous events are most likely to be described using an aspectual construction. For example, in describing a person standing at a river fly fishing, where the same action of casting the line is repeated continuously, the aspectual construction was used in 20 out of 23 utterances $(86.9 \%)$. For the scene with a person standing and conducting an orchestra, the occurrence is lower: 10 out of 23 utterances (43.4\%), and for the scene showing street musicians playing different instruments it was even lower: seven out of 23 utterances $(30.4 \%)$.

Situations in which the characters change place show markedly low occurrence of aspectual expressions. For example, in describing surfing, four utterances out of 23 contained an aspectual construction (17.39\%), playing table tennis (moving back and forward to reach the ball)-four out of $23(17.39 \%)$. These tentative findings indicate the role of the factor change in place for the use of aspectual constructions linked to 


\section{Behrens, Flecken, and Carroll}

posture, as the occurrence of aspectual constructions is high for the activity situation type (no change of state), in cases where there is no change in place on the part of the characters.

The reduced tendency to accommodate change-in-place situations on a systematic scale, particularly when goal-oriented, indicates a general constraint on posture verb constructions across the two languages Dutch and Norwegian. Also, in line with the role of posture verbs, we found that situations with low dynamicity do not differ significantly from highly dynamic situations in attracting the use of posture verb constructions in Norwegian. This contrasts with Dutch, where high dynamicity of the situation and its progressive component clearly attracts aspect marking, but notably-the aan het-construction rather than a posture verb. A summary of the results for Dutch and Norwegian is given in table 7 .

\begin{tabular}{llllll}
\hline & Dutch & \multicolumn{3}{l}{ Norwegian } & \\
\hline & aan het & $\begin{array}{l}\text { Posture } \\
\text { verb }\end{array}$ & $\begin{array}{l}\text { Posture } \\
\text { verb }\end{array}$ & driver & $\begin{array}{l}\text { Prospec } \\
\text { group }\end{array}$ \\
\hline $\begin{array}{l}\text { No change in } \\
\text { state: } \\
\text { activities }\end{array}$ & $49.57 \%$ & $12 \%$ & $30.9 \%$ & $1.40 \%$ & $6.28 \%$ \\
\hline $\begin{array}{l}\text { Change in } \\
\text { state: effected } \\
\text { object }\end{array}$ & $55.90 \%$ & $4.17 \%$ & $18.14 \%$ & $3.33 \%$ & $0.37 \%$ \\
\hline $\begin{array}{l}\text { Change in } \\
\text { state: affected } \\
\text { object }\end{array}$ & $49.38 \%$ & $1.25 \%$ & $8.67 \%$ & 0 & 0 \\
\hline $\begin{array}{l}\text { Change in } \\
\text { state: } \\
\text { low scale }\end{array}$ & $7.50 \%$ & $4.37 \%$ & $16.00 \%$ & $0.69 \%$ & $3.89 \%$ \\
\hline $\begin{array}{l}\text { Motion event: } \\
\text { goal not } \\
\text { reached }\end{array}$ & $1.82 \%$ & 0 & $0.28 \%$ & $0.56 \%$ & $5 \%$ \\
\hline $\begin{array}{l}\text { Motion event: } \\
\text { goal reached }\end{array}$ & 0 & 0 & 0 & & \\
\hline
\end{tabular}

Table 7. Summarized results for Dutch and Norwegian. 
The comparison illustrates the differences in frequency of use of posture verbs between Dutch and Norwegian given the same task. It also highlights the relevant features of the aan het-construction that distinguish it from posture verbs.

\section{German: Frequency of Use and Qualitative Analysis.}

Table 8 below provides an overview of the types of situations in which aspectual constructions in German were used. In contrast to the other two languages, the overall rate of occurrence was very low: $1.41 \%$. Since the occurrence is very low, with 22 cases in all, compared to 217 in Norwegian and 443 in Dutch, the situation in German can be characterized by an overall absence of aspectual constructions. As the following table shows, in 17 cases out of 22 aspectual constructions were used in descriptions of situations with no change in state.

\begin{tabular}{|c|c|c|c|c|}
\hline $\begin{array}{l}\text { Situation } \\
\text { type }\end{array}$ & $\begin{array}{l}\text { am } \\
+ \text { verbal noun }\end{array}$ & $\begin{array}{l}\text { beim } \\
+ \text { verbal noun }\end{array}$ & $\begin{array}{l}\text { dabei sein zu } \\
+ \text { inf }\end{array}$ & Total \\
\hline $\begin{array}{l}\text { No change in } \\
\text { state }\end{array}$ & $\begin{array}{l}1 / 160 \\
0.63 \% \\
\end{array}$ & $\begin{array}{l}14 / 160 \\
8.75 \%\end{array}$ & $\begin{array}{l}2 / 160 \\
1.25 \% \\
\end{array}$ & $17(/ 160)$ \\
\hline $\begin{array}{l}\text { Change in } \\
\text { state: effected }\end{array}$ & 0 & $\begin{array}{l}1 / 288 \\
0.35 \% \\
\end{array}$ & $\begin{array}{l}3 / 288 \\
1.04 \% \\
\end{array}$ & $4(/ 288)$ \\
\hline $\begin{array}{l}\text { Change in } \\
\text { state: affected }\end{array}$ & 0 & $\begin{array}{l}1 / 160 \\
0.63 \%\end{array}$ & 0 & $1(/ 160)$ \\
\hline $\begin{array}{l}\text { Change in } \\
\text { state: low scale }\end{array}$ & 0 & 0 & 0 & $0(/ \mathbf{3 8 4})$ \\
\hline $\begin{array}{l}\text { Motion events: } \\
\text { goal not reached }\end{array}$ & 0 & 0 & 0 & $0(/ 224)$ \\
\hline $\begin{array}{l}\text { Motion events: } \\
\text { goal reached }\end{array}$ & 0 & 0 & 0 & $0(/ \mathbf{3 8 4})$ \\
\hline Total & $1 / 1600$ & $16 / 1600$ & $5 / 1600$ & \\
\hline
\end{tabular}

Table 8. Types of aspect markers used in the German data (frequency of use as a percentage of all utterances for the situation type).

Overall, the beim-construction is used most frequently in descriptions of no-change-in-state situations, both with and without the finite verb (see 16a,b below). The beim-construction does not combine (syntactically) 
with a direct object: Er ist *den Kuchen beim Backen lit. 'he is *the cake at the bake'. Nor can one relate to a specific subevent (indicating a change in state) with this form: Er ist *beim Mehl in den Schüssel tun lit. '*he is at flour in the bowl put'. The form used in this case is dabei, as in Sie sind dabei, Mehl in den Schüssel zu tun lit. 'They are there-at flour in the bowl to put'. Its use depends on the possibility of abstracting away from individual subevents, as in Er ist beim Kuchenbacken lit. 'He is at the.DAT cake-baking', and holistically depicting an event as a "macroevent", for example, beim Backen lit. 'at the baking' or beim Fu $\beta$ ballspielen lit. 'at the football-playing', as shown in 16 (for detail, see Carroll \& von Stutterheim 2011).

(16) a. Ein Angler ist beim Fliegenfischen.

a fisherman is at-the flyfishing

'A fisherman is fly fishing.'

b. Ein Geiger beim Geigespielen.

a violinist at-the violinplaying

'A violinist is playing the violin.'

Even though the am-construction is possible in this context, it is used less frequently than the beim-construction in the current data set.

With respect to the dabei sein-construction, in other data sets collected in previous studies using the same methodology (see Carroll et al. 2008, von Stutterheim et al. 2009), a preference for this construction was found in the description of motion events, even though the use was still rare, as exemplified in 17.

(17) Eine Frau ist dabei die Strasse zu überqueren.

a lady is there-at the street to cross

'A lady is crossing the street.'

It is not possible to use the construction with beim to describe change-inplace events: *Sie ist beim Straße überqueren lit. 'She is at the.DAT streetcrossing'.

In sum, the present findings indicate that explicit means for the expression of aspect are too constrained to be considered a grammatical option in Standard German (see also Booij 2008). They are clearly not 
considered appropriate for use in the present setting. The very low occurrence of aspectual constructions in the German data does not allow us to draw any conclusions on patterns of their use. Therefore, this language is not included in the overall summary below.

\section{Discussion.}

\subsection{The Results for Dutch.}

Dutch speakers used aspectual constructions when describing video clips showing different types of situations in $27.52 \%$ of cases. Situations showing a change in state (effected or affected object, high dynamicity), as well as those showing no change in state (for example, playing the violin) are equally likely to be described by predicates marked for aspect. With regard to form, the aan het-construction occurred with higher frequency ( 375 occurrences, or $84.65 \%$ ) than posture verb constructions (59 occurrences, or $13.31 \%$ ).

Previous research labeled the aan het-construction a marker of progressive aspect but provided no clear definition of progressive in terms of features that constrain or attract the use of a particular construction (Boogaart 1991, 1999; Ebert 1996, 2000; van Pottelberge 2004; Booij 2008). The present experimental study has identified a range of empirical arguments in support of the claim that the Dutch aan hetconstruction has a progressive component. Its high occurrence in descriptions of change-in-state situations with highly dynamic changes demonstrates this. By contrast, the occurrence of the aan het-construction in descriptions of change-in-state situations with low dynamicity (for example, a candle burning down) is very low.

The present study reveals that the choice of a posture verb is determined by the posture of the main character in the situation. There are, however, corpus studies showing that this is not a strict requirement, as mismatches are sometimes observed between the posture in a situation and the posture verb used to describe it (for example, Ebert 2000, Lemmens 2005). With regard to situation type, the occurrence of posture verbs is high in descriptions of situations showing no change in state, and it is markedly lower in descriptions of change-in-state situations, in contrast to the aan het-construction. The occurrence of posture verbs in descriptions of situations with low dynamicity shows that posture verbs are selected even when the physical force driving the change in state is not a visible agent. This is contrary to what has been claimed in some 
studies on Dutch (Ebert 2000) and on the use of posture verbs and other constructions that mark aspect (Tonne 1999, 2007; Bertinetto et al. 2000; Hundt 2004). The data thus indicate that the use of posture verb constructions is not strictly constrained by agentivity (see, for example, Traugott \& Heine 1991, Bybee 1994, Tonne 1999, Lemmens 2005).

At the level of the predicate and its semantic features, Ebert (1996, 2000) discusses linguistic factors (that is, properties of the linguistic form rather than the situation, as in the present study) that may affect the choice between the aan het-form and a posture verb construction. She observes that the posture verbs may be preferred "with verbs of low dynamicity like sleep, wait, look" (Ebert 2000:53). Other possible factors discussed relate to telicity, which also leads to the use of aan het (Ebert 2000). We note that telicity relates to the perfectivity of predicates determined by the verbs used rather than properties of the situation. Although our frame of analysis differs from Ebert 2000 in this respect, we see that there are similar findings, in part at least, with those of the present study.

Situations that involve a goal-oriented change in place do not attract the use of aspectual constructions in Dutch. Aspectual constructions are only used when this situation type is explicitly represented as an activity, for example, being out for a walk, as in Een meisje is door een park aan het wandelen 'A girl is taking a stroll through the park'. Utterances of this kind (being out for a walk, taking a stroll) do not describe goaloriented motion, in contrast to the motion-event situations depicted in the video clips. This pattern contrasts with English, for example, where the progressive form is used in 100\% of all situation types: A car is driving toward a petrol station is fine, but its Dutch equivalent ?een auto is naar een benzinestation aan het rijden is distinctly odd. In Dutch, the occurrence of an aspectual form is almost zero in situations of this type. As noted in the introduction (section 1.3), the occurrence of an aspect marker with this situation type is also low in other languages where aspect marking is still optional (for example, Italian) and has not (yet) reached frequencies for change-in-state situations that do not involve a change in place. Since the aan het-marker is to some extent (still) incompatible with goal-oriented motion, we can conclude that it has not reached the level of abstraction found for the English progressive. 


\subsection{The Results for Norwegian.}

The frequency with which aspectual constructions are used is limited to $14.5 \%$ in all utterances. They are used most frequently to describe situations that do not involve a change in state (38.65\%), while their use in descriptions of situations with a change in state and an effected object, as well as those with low dynamicity are significantly lower $(21.85 \%$ and $18.67 \%$, respectively). This means that situations with a change in state and high dynamicity (+progressive component), as well as those without these properties (low dynamicity and a change of state), are almost equally likely to lead to the use of an aspectual construction. The temporal property associated with scenes showing progression toward a resultant state is thus not relevant for the use of aspectual constructions in Norwegian. In this sense, there is no evidence that the forms have a distinct progressive component. Note that the change-in-state situations with an effected object mainly attract the posture verb pseudocoordinations. With respect to the other two situation types, posture verb constructions are by far the most frequent choice, although the descriptions of these situation types demonstrate a greater variety of expressions.

A more detailed analysis of change-in-state situations reveals that the constructions are sensitive to homogeneous versus heterogeneous events. In Norwegian, homogeneity is therefore also a relevant factor, just as in Dutch. Norwegian differs from Dutch, however, in attracting some aspectual constructions for goal-oriented motion events. The constructions er ute og 'to be out' and er pa vei 'to be on one's way' are occasionally used to describe this situation type, but overall their occurrence is relatively low.

The pseudocoordination driver 'drift' does not require a particular posture of the event participant and is thus less constrained semantically than posture verb constructions. One might therefore expect a higher frequency of use than the posture verb constructions, but this turned out not to be the case, possibly because the stimulus set did not include scenes that were neutral with respect to physical posture. However, the very few scenes attracting the use of the driver og-form suggest that the structure is not at present a strong competitor for the other forms in Norwegian.

These findings suggest that the posture pseudocoordinations in Norwegian are expressions of temporary localizations in space (stand- 
sit-lie) that contribute to the interpretation of the description of a situation in two ways: They "localize" the subject referent in space (statively), and their temporary state denotation adds temporariness to the situation expressed by the main verb. The fact that goal-oriented motion events on the whole do not attract the use of posture verb constructions can then be explained, of course, by the fact that motion by its very nature conflicts with the state-locational meaning of the posture verbs. This indicates that posture verb constructions are not grammaticalized aspectual forms, since they retain a strong lexical component. At the same time, the variety of means available and chosen to mark aspect allows us to speculate that a possible grammaticalization process that involves marking of unboundedness is at least in its initial stage. According to Hopper \& Traugott 1993:104, 124, the coexistence of diverse forms within a single functional domain - a case of "layering"may be a synchronic indication of this process.

\section{Conclusion.}

In the present study, situations presented in video clips were varied on a systematic basis with regard to a specific set of properties in order to trace factors underlying the selection of aspectual distinctions in Dutch, Norwegian, and German. The occurrence of aspectual marking was highest in Dutch $(27.52 \%)$, followed by Norwegian $(14.50 \%)$. In German, the occurrence was so low $(1.41 \%)$ that it was not considered any further in the present comparison. Although the frequency of use of various aspectual constructions varies in both Dutch and Norwegian, posture verb constructions follow a similar pattern in the two languages: They are most frequently used to describe situations showing no change in state.

This contrasts with the periphrastic aan het-construction in Dutch: Its occurrence is high with situations showing a change in state and a progressive component, as well as those showing no change in state. Based on the clear preference for posture verbs in descriptions of situations with no change in state (activities), we conclude that there is no evidence that they have a progressive component in either Dutch or Norwegian. In addition to the situation types and their temporal properties, the findings show that homogeneity of events is relevant as it increases the frequency of use of aspectual constructions in descriptions of the relevant situation types in both languages. In contrast to all other 
situation types in the study, predicates describing goal-oriented motion events are not marked for aspect in Dutch. This finding correlates to a certain degree with the results for other languages dealt with in previous experiments, as mentioned in the introduction. In Italian and Spanish, for example, as well as in Dutch, the occurrence of aspectual forms is lower in cases when the change in place is focused. Again, this overall pattern on a possible road to grammaticalization may be linked to the mainly locative roots of the different means in these languages. Although Norwegian, as opposed to Dutch, has separate forms to express aspect with goal-oriented motion events, their use is infrequent.

The fact that Norwegian has a variety of partially overlapping forms to express aspect suggests that aspect marking is potentially grammaticalizing in this language. However, it is lower on the grammaticalization cline than it is in Dutch. No particular expression has shown itself as a "winning candidate" for the expression of progression, and the prospec forms are used infrequently in the contexts examined in this study. In this sense, the means of expressing aspect are not grammaticalizing at this point, assuming the paradigm case "in which a lexical item in a syntactic periphrastic construction gradually evolves into an inflectional affix" (Haspelmath 1992:71; see also Bybee et al.1994). Furthermore, it is not at all clear that the posture verb constructions in Norwegian will develop into grammatical means of expressing the progressive aspect.

In Dutch, the less lexically-specified aan het-construction is preferred across the board, indicating its grammaticalization as an aspectual marker, that is, the more abstract expression is predominant in Dutch. By analogy, we speculate that the highly informal driver og 'drifts away and' may find its way into the standard language as a marker for progression. Yet the pseudocoordinate structure with two finite verb forms may require too much of the lexical content of the individual verbs to ever develop into a fully grammaticalized aspect marker. ${ }^{8}$ We thus

\footnotetext{
${ }^{8}$ Hilpert \& Koops (2008) conducted a quantitative study on the use of pseudocoordintation with the verb sit in Swedish, showing that this construction was already in use around 1350-1400. The frequency of use in novels has increased significantly since then, but there has been no significant difference in frequency in the last 120 years. They do not examine the use of the verb in relation to different situation types, so no changes in contextually determined distribution can be deduced on the basis of their study.
} 
conclude that Dutch is "ahead" of Norwegian with respect to grammaticalization of particular aspectual forms.

With regard to one of the core questions, namely, whether or not the constructions studied can be adequately described as progressives, and based on the features studied in the present framework (see table 2 above), we suggest the following contrasts and scale of grammaticalization for the means in Norwegian and Dutch.

Aspectual meaning:

Ongoing
Aspectual meaning:

Progression/Ongoing

Higher grammatical status

\section{Dutch aan het-construction}

Norwegian posture verb constructions

semantic bleaching/abstraction weak

semantic bleaching strong

homogeneity of events relevant

homogeneity of events relevant

progressive component

(inherent endpoint of situation)

not relevant

constraint: change in place focused

progressive component relevant

constraint: change in place focused

(exception for form $p a ̊ v e i$

'on one's/its way')

Figure 2. Scale of grammaticalization with relevant factors.

The aan het-construction exhibits both features in the following sense: It is used with change-in-state situations with a progressive component, as well as situations that involve inherently nonprogressive activities which can be viewed as ongoing. The latter may involve motion but not a focus on the change in place as such, as when motion is goal-oriented. Taking English as a point of reference, the semantics of posture verb expressions in Norwegian and Dutch is nowhere near as abstract as that of the progressive form in English. As for Dutch, the posture verb constructions are used infrequently in the present context, and the grammaticalizing aan het-construction is the kind of form out of 
which progressives often develop - a periphrastic construction with a copula plus a verbal noun in a prepositional locative phrase (see Sasse 2002). Finally, the locative meaning of the Norwegian posture verb constructions seems rather stable, so the likelihood of further abstraction of this type of construction may be rather low.

The present study illustrates the advantages of looking at actual language use based on identical input when analyzing the nature of the forms available in different languages. By correlating the use of linguistic means with the actual visual input, that is, properties manipulated on systematic terms in the situations presented, the informants' choice of expression can be compared across languages, allowing generalizations over the function of the different aspect markers on this basis. This would not be possible in a study based on corpus data. Naturally, we are aware of the limitations of the study, which are, to name a few, differences between situation types that were not counterbalanced in the present design with regard to the number in each category, overall event duration (although the excerpts shown are similar in length, knitting a scarf will take longer than drawing a tree (line drawing), for example), etc. Also, we are aware that relevant cases of analyses could be provided by looking at the use of aspect in narratives, for example, where we have a complex set of overlapping, sequencing, fore- and backgrounded events, etc. The present findings can be viewed as pointers toward a set of factors that influence progressive attraction. However, repeated studies over time, based on the same visual input, and modified to include more scenes that are neutral to posture, can make an important contribution to the study of the factors that lead to progressive attraction.

\section{REFERENCES}

Bertinetto, Pier Marco, Karen Ebert, \& Casper de Groot. 2000. The progressive in Europe. Tense and aspect in the languages of Europe, ed. by Östen Dahl, 517-558. Berlin: Mouton de Gruyter.

Bjerre, Tavs, \& Anne Bjerre. 2007. Pseudocoordination in Danish. Proceedings of the HPSG '07 Conference, ed. by Stefan Müller, 6-24. Stanford: CSLI Publications.

Boogaart, Ronny. 1991. Progressive aspect in Dutch. Linguistics in the Netherlands, ed. by Frank Drijkoningen \& Ans van Kemenade, 1-9. Amsterdam: John Benjamins. 
Boogaart, Ronny. 1999. Aspect and temporal ordering: A contrastive analysis of Dutch and English. The Hague: Holland Academic Graphics.

Booij, Geert. 2008. Constructional idioms as products of linguistic change: The aan het + infinitive construction in Dutch. Constructions and language change, ed. by Alexander Bergs \& Gabriele Diewald, 79-104. Berlin: Mouton de Gruyter.

Bybee, Joan. 1994. The grammaticization of zero. Perspectives on grammaticalization, ed. by William Pagliuca, 235-254. Amsterdam: John Benjamins.

Bybee, Joan, Revere Perkins, \& William Pagliuca. 1994. The evolution of grammar: Tense, aspect, and modality in the languages of the world. Chicago: The University of Chicago Press.

Carroll, Mary, Silvia Natale, \& Marianne Starren. 2008. Acquisition du marquage du progressif par des apprenants germanophones de l'italien et néerlandophones du français. AILE 26.31-50.

Carroll, Mary, \& Christiane von Stutterheim. 2011. Event representation, eventtime relations and clause structure: A cross-linguistic study of English and German. Event representation in language: Encoding events at the languagecognition interface, ed. by Jürgen Bohnemeyer \& Eric Pederson, 68-83. Cambridge: Cambridge University Press.

Comrie, Bernard. 1976. Aspect. Cambridge: Cambridge University Press.

Dahl, Østen (ed.). 2000. Tense and aspect in the languages of Europe. Berlin: Mouton de Gruyter.

Ebert, Karen. 1996. Progressive aspect in German and Dutch. Journal of Germanic Linguistics and Literature 1. 41-62.

Ebert, Karen. 2000. Progressive markers in Germanic languages. Dahl 2000, 605-653.

Flecken, Monique. 2011a. What native speaker judgements tell us about a progressive aspectual marker in Dutch. Linguistics 49. 479-524.

Flecken, Monique. 2011b. Event conceptualization by early bilinguals: Insights from linguistic and eye tracking data. Bilingualism: Language \& Cognition 14. 61-77.

de Groot, Casper. 2000. The absentive. Dahl 2000, 641-667.

Haspelmath, Martin. 1992. Grammaticalization theory and heads in morphology. Morphology now, ed. by Mark Aronoff, 69-82. Albany: State University of New York Press.

Hilpert, Martin, \& Christiane Koops. 2008. A quantitative approach to the development of complex predicates. The diachrony of complex predication (Diachronica 25), ed. by Claire Bowern, 242-261.

Hopper, Paul, \& Elizabeth Closs Traugott. 1993. Grammaticalization. Cambridge: Cambridge University Press. 
Hundt, Marianne. 2004. Animacy, agentivity, and the spread of the progressive in Modern English. English Language and Linguistics 8. 47-69.

Klein, Wolfgang. 1994. Time in language. London: Routledge.

Krause, Olaf. 2002. Progressive Verbalkonstruktionen im Deutschen: Ein korpusbasierter Sprachvergleich mit dem Niederländischen und dem Englischen. Tübingen: Niemeyer.

Kvist-Darnell, Ulrika. 2008. Pseudosamordningar i svenska, säskilt sådana med verben sitta, ligga och stå. $\mathrm{PhD}$ dissertation, Stockholm University, Stockholm.

Leclerq, Pascale. 2008. L'influence de la langue maternelle chez les apprenants adultes quasi-bilingues dans une tâche contrainte de verbalisation. AILE 26. 51-70.

Leys, Odilon. 1985. De konstruktie staan te + infinitief en verwante konstrukties. Verslagen en Mededelingen van de Koninklijke Akademie voor Nederlandse Taal- en Letterkunde 3. 265-277.

Lemmens, Maarten. 2005. Aspectual posture verb constructions in Dutch. Journal of Germanic linguistics 17. 183-217.

Lødrup, Helge. 2002. Norwegian pseudocoordinations. Studia Linguistica 56. 121-143.

Natale, Silvia. 2009. Gebrauchsdeterminanten der verbalperiphrase stare + gerundio. Tübingen: Narr Verlag.

van Pottelberge, Jeroen. 2004. Der Am-Progressiv. Tübingen: Narr Verlag.

Sasse, Hans Jürgen. 2002. Recent activity in the theory of aspect:

Accomplishment, achievement, or simply non-progressive state? Linguistic Typology 6. 199-271.

Schmiedtová, Barbara. 2011. Do L2 speakers think in the L1 when speaking in the L2? VIAL International Journal of Applied Linguistics 8. 97-122.

Smith, Carlota. 1991. The parameter of aspect. Dordrecht: Kluwer Academic Press.

von Stutterheim, Christiane, Mary Carroll, \& Wolfgang Klein. 2009. New perspectives in analyzing aspectual distinctions across languages. The expression of time, ed. by Wolfgang Klein \& Ping Li, 195-216. Berlin: Mouton de Gruyter.

von Stutterheim, Christiane, Martin Andermann, Mary Carroll, Monique Flecken, \& Barbara Schmiedtová. 2012. How grammaticized concepts shape event conceptualization in language production: Insights from linguistic analysis, eye tracking data, and memory performance. Linguistics 50. 833867.

Telemann, Ulf, Staffan Hellberg, \& Erik Andersson. 1999. Svenska Akademiens grammatik. Stockholm: Norsteds.

Tonne, Ingeborg. 1999. A Norwegian progressive marker and the level of grammaticalization. Languages in Contrast 2. 131-161. 
Tonne, Ingeborg. 2006. Elucidating progressives in Norwegian. A Festschrift for Kjell Johan Sab $\phi$ : In partial fulfillment of the requirements for the celebration of his 50th birthday, ed. by Torgrim Solstad, Atle Grønn, \& Dag Trygve Truslew Haug. Oslo: Oslo University College/Unipub.

Tonne, Ingeborg. 2007. Analyzing progressives in Norwegian. Nordic Journal of Linguistics 30. 185-208.

Traugott, Elizabeth Closs, \& Berndt Heine. 1991. Approaches to grammaticalization, vol. II: Focus on types of grammatical markers. Amsterdam: John Benjamins.

Vannebo, Kjell Ivar. 1969. Aksjonsart i norsk: Ein syntaktisk funksjonsanalyse. Oslo: Universitetsforlaget.

Vendler, Zeno. 1957. Verbs and times. The Philosophical Review 66. 143-160.

Bergljot Behrens

Department of Literature, Area Studies, and European Languages

University of Oslo, pb 1003

0315 Oslo

Norway

[bergljot.behrens@ilos.uio.no]

Monique Flecken

Radboud University

Donders Centre for Cognition

Montessorilaan 3, 6525 HR Nijmegen

The Netherlands

[m.flecken@donders.ru.nl]

Mary Carroll

Institut für Deutsch als Fremdsprachenphilologie

Heidelberg University

Plöck 55, 69117 Heidelberg

Germany

[carroll@idf.uni-heidelberg.de] 